\title{
Home range and habitat use by pacas in a montane tropical forest in Bolivia
}

\author{
Camila BENAVIDES, Alejandro ARCE, Luis F. PACHECO* \\ 1 Instituto de Ecología, Universidad Mayor de San Andrés, P.O. Box 10077, Correo Central, La Paz, Bolivia \\ * Corresponding author: luisfpachecoa@gmail.com
}

\section{ABSTRACT}

We studied the home range and habitat use of paca (Cuniculus paca) in a rural agricultural community in the Alto Beni region, in La Paz department, Bolivia, where game meat is the main source of protein for a large portion of local inhabitants. We captured and radio collared five individual paca ( 4 females and 1 male), which were followed for six months in 2012 to estimate home range of the individuals and assess their habitat use and selection. The total mean home range (95\% Minimum Convex Polygon) was 2.26 ha $(S D=0.80)$, and ranged from 1.5 to 2.96 ha. The mean female home range $(2.04$ ha) was smaller than the male's (2.95 ha). Pacas used two (crops and fallows) of the three available habitats (secondary forest patches), and appeared to positively select crops over the other two. The importance of crops may be linked to the type of agriculture conducted in the area (i.e. mainly cacao in agroforestry systems), which may offer more food and shelter for pacas. Given that, the importance of habitats may change seasonally; this topic should be examined in future studies. Our results suggest that agroforestry systems may be important for the species since they offer a variety of food resources throughout the year.

KEYWORDS: space use, radiotelemetry, Alto Beni, cacao, agroforestry

\section{Ámbito de hogar y uso de hábitat del jochi pintado en un bosque montano tropical de Bolivia}

\section{RESUMEN}

Hemos estudiado el ámbito de hogar y uso de hábitat del jochi pintado (Cuniculus paca) en una comunidad de Alto Beni en el Norte de La Paz-Bolivia, donde la carne obtenida por cacería es, como en muchas regiones de la Amazonia, una fuente principal de proteína para muchas poblaciones indígenas y campesinas. Hemos capturado y seguido con radio-collar a cinco individuos (4 hembras y 1 macho) por seis meses en 2012. El ámbito de hogar promedio de los individuos fue de 2,26 ha (ds=0,80), usando el estimador Mínimo Polígono Convexo (MPC al 95\%) y los valores se encuentran entre 1,5 a 2,96 ha. El ámbito de hogar promedio de las hembras fue más pequeño (2,04 ha) que del macho (2,95 ha). Los jochis estudiados usaron 2 (cultivos y barbechos) de los 3 hábitats disponibles (parches de bosque secundario), aunque los cultivos parecen ser seleccionados positivamente respecto a los otros dos. La importancia de los cultivos podría estar ligada al tipo de cultivo que se realiza en la zona (sistemas agroforestales), que podrían estar ofreciendo mejores condiciones para ser usados por los jochis. Adicionalmente, la importancia de los hábitats podría cambiar de acuerdo a la época del año, lo cual podría ser abordado en siguientes estudios. Este trabajo es el primero en dar detalles sobre la ecología de C. paca en vida silvestre en Bolivia; sin embargo sería necesario contar con más individuos para tener más detalle sobre la ecología espacial de esta especie.

PALABRAS CLAVE: uso de hábitat, radiotelemetría, Alto Beni, cacao, agroforestería 


\section{INTRODUCTION}

Paca is the second largest rodent in the Neotropics (Pérez 1992; Queirolo et al. 2008), inhabits forests from Mexico to northern Argentina (Pérez 1992) and is one of the most commonly hunted species in Central and South America (Redford and Robinson 1991; Zapata 2001; Queirolo et al. 2008; Aquino et al. 2009; Gallina et al. 2012; Santos-Fita et al. 2012). It has been surveyed extensively across its distribution, but little is known about its spatial ecology (Wallace et al. 2010). Several studies have been conducted focusing on paca behavior, abundance and management in captivity (Parroquin 2010, Rodriguez and Ortega 2012), diet (Beck-King et al. 1999, Zucaratto et al. 2010), its exploitation by humans (Aquino et al. 2009, Aspirilla-Perea et al. 2011, Gallina et al. 2012), and just a handful report data on home range (Marcus 1984, Smythe and Brown de Guanti 1995), with only one using radiotelemetry as a monitoring tool (Beck-King et al. 1999). Finally, there is limited specific information focused on the habitat use and preference of the species (Guzmán -Aguirre 2008, Goulart et al. 2009, Michalsky and Norris 2011, Huanca-Huarachi et al. 2011, Aquino et al. 2012).

Information on the population dynamics is of crucial importance for the management of a species, whatever its goal (Sutherland 2000). However, behavioral aspects, like home range, and habitat use studies are also important, since they give insights into how much habitat a species uses during their daily activities (i.e. home range), where individuals are likely to be found most frequently, and which resources may be selected by them (i.e. habitat use, and selection; Powell 2000, Manly et al. 2002).

Marcus (1984) reports home range sizes of 0.7 ha for juvenile males, and 1.8 ha for adult females in Panama, whereas Smythe and Brown de Guanti (1995) report home ranges between 3 and 4 ha, based on direct observations in Colombia and Panama. Finally, radio tracking of a juvenile male and an adult female in a humid forest in Costa Rica registered home ranges of 1.5 and 2.3 ha, respectively (Beck-King et al. 1999). Pacas are found in mangroves, semideciduous forests, riparian vegetation and sites with dense undergrowth, always near water sources (Pérez 1992; Guzmán-Aguirre 2008; Wallace et al. 2010). They tolerate, and even do better in non-intensively-cultivated land (Roldán and Simonetti 2001; Guzmán-Aguirre 2008; Parroquin et al. 2010). Using tracks and fecal surveys at Sierra Tabasco, Mexico, Guzmán-Aguirre (2008) found that pacas prefer primary forest over secondary forests and fallows; he never found paca signs in croplands. In contrast, Pérez and Pacheco (2006) report frequent use of agricultural fields by pacas in a Bolivian Yungas Montane forest (1200-1600 m). The only study on habitat use in Bolivia was based on direct and indirect (tracks) observations at Parque Nacional Amboró. Even though the density of pacas was similar in the sampled habitats, the study found a positive correlation between the species' density and mean diameter at breast height of dominant tree species, suggesting a higher population density of pacas in mature forests (Huanca-Huarachi et al. 2011).

Our main objective was to assess home range and habitat use by pacas in a region dominated by agroforestry systems and subjected to unregulated subsistence hunting. Since the species is reported to be monogamous (Pérez 1992), we predicted similar home range sizes for males and females. Given that different habitats bear differences in food availability, we predicted that individuals would differ in their use of habitat, in accordance to habitat availability.

\section{MATERIALS AND METHODS}

\section{Study Area}

The study was carried out at Remolinos (15'41' to $15^{\circ} 42^{\prime}$ $S$ and $67^{\circ} 04^{\prime}$ to $67^{\circ} 06^{\prime} \mathrm{W},-2800 \mathrm{ha}$ ), a rural agricultural community within Palos Blancos Municipality, La Paz department, Bolivia (Figure 1). The area's mean elevation is $450 \mathrm{~m}$, and presents moderate to steep slopes. The vegetation is represented by a diversity of Amazonian and sub-Andean species. Between 300 and $500 \mathrm{~m}$, it is classified as a transitional amazonian forest, with trees up to $40 \mathrm{~m}$ in height, and up to $150 \mathrm{~cm}$ in diameter and also sub-montane forests (500 to $600 \mathrm{~m}$ ). Above $600 \mathrm{~m}$ there is a montane humid evergreen forest (PIAF-El Ceibo 2002). Crops and fallows cover most of the community's lands; the latter are dominated by several species of Gramineae, various families of shrubs, and pioneer tree species such as Cecropia spp., Ochroma pyramidale and various species of Inga (PIAF-El Ceibo 2002).

The main economic activity in Remolinos is agriculture, using agroforestry systems which combine rice, corn, water melon, banana, squash, manioc, peanuts, papaya and other various species of Citrus spp. Cacao (Theobroma cacao) is the most common commercial crop. People used to extract wood for commercial purposes, especially Swietenia macrophylla, Amburana cearensis, and Cedrela odorata (Quintana and Vargas 1995). Although, these species are rarely found today in natural vegetation, they are being regrown inside the crop areas with trees up to around 20 years old. Finally, some palms (Attalea phalerata) and fruit trees (Averrhoa carambola, Garcinia madruno, and Hymenaea courbaril) are grown for people's own consumption, increasing the diversity of agricultural habitats.

\section{Capturing pacas}

Pacas were captured with the help of a hunter and his trained dogs, between May and June 2012. Dogs searched freely within community boundaries until they discovered an occupied paca den. The hunter searched for other den 


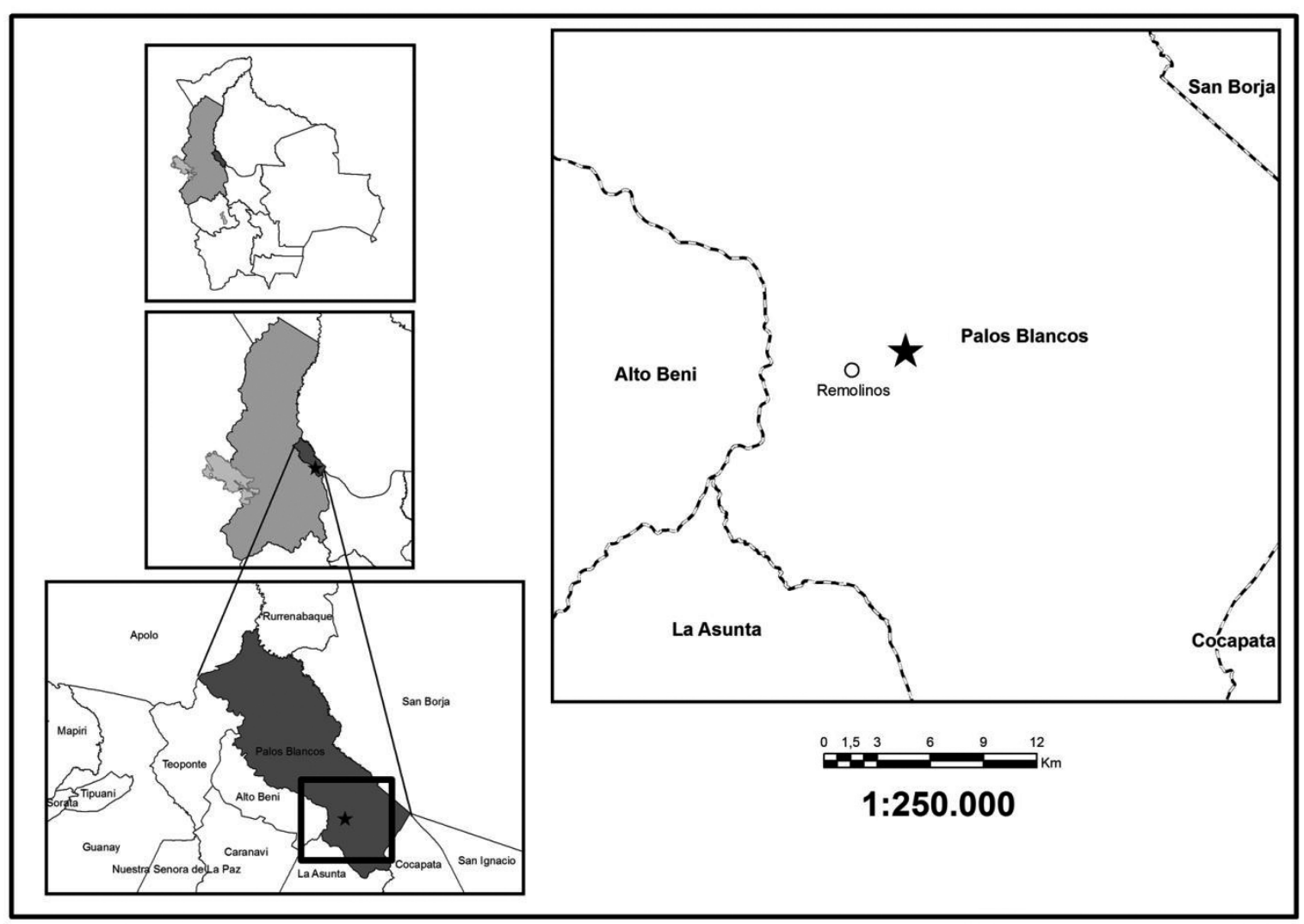

Figure 1. Study area for the pacas (Cuniculus paca) radio tracked at Remolinos, Alto Beni, Bolivia.

entrances, and closed all but one. He then smoked the den and waited until the paca tried to escape, closing the main entrance with a plastic bag. Once the animal entered the plastic bag, the hunter rapidly subdued it by hand, and put it into a Havahart type cage $(100 \times 40 \times 40 \mathrm{~cm})$, covered with foam on the inside, to reduce the risk for the animal to injure itself when trying to escape. The captured individual was later moved to a safe place to manipulate it, where it was sedated with an intramuscular injection of a mixture of Xilacine and Ketamine at 10\% (Ávila 2007; Zolotoff-Pallais and Lezama 2009). We then removed the animal from the trap, to take standard measurements and weight, and to fit it with a radio collar (Advanced Telemetry Systems, M2320B, $130 \mathrm{~g}$ ). The animal was returned to the cage within $\sim 15$ minutes, where it was kept until it was fully awake. The animal was provided food and water until it was released at the point of capture, georeferenced with a Garmin GPS receiver, at sunset (less than 12 hs after its capture). Animal handling techniques, and research permits were approved by Bolivian National Authorities; and comply with ASM guidelines (Sikes and Gannon 2011). We allowed one week for pacas to return to normal activities after capture before any data acquisition.

\section{Radio tracking}

One week after individual animals were captured, we searched for them using the homing technique (White and Garrot 1990), during daylight hours. The position of each den was recorded on a GPS receiver. We then initiated nocturnal radio tracking of individuals, initially to assess their general movement area. Afterwards, we located several fixed points to obtain azimuths for triangulation. Radio tracking was done with an ATS receiver (R410), from June-November 2012 (dry season). We obtained one or two locations for each individual every night (between 17:00 and 7:00 hs.), although we did not get any data when rain was intense. For each location, we took a first azimuth from a georeferenced point where we found the best signal and then chose a second point to take another azimuth. Given that we only had one receiver, we had to restrict our data to two azimuths taken with a maximum of three-minute intervals, to ensure that the animal did not move much before we completed both azimuths to obtain a location. Azimuths were separated at least $20^{\circ}$ (Millspaugh et al. 2012). If we were able to obtain two radio locations for any individual in a single night, they had to be separated by at least $60 \mathrm{~min}$ to ensure independence of data (Powell 
2000). Data were analyzed with LOAS to obtain locations, and BIOTAS software to estimate home range (Ecological Software Solutions 2005).

\section{Estimation of home range and overlap}

The home range and core area estimates were based on the Minimun Convex Poligon (MCP; Powell 2000; AliagaRossel 2004; Castellanos 2006). We used $95 \%$ of data and eliminated extreme locations. The core area (i.e. area of high or priority use) was estimated with $50 \%$ of locations (Powell 2000). We chose MPC because of its known simplicity, and flexibility of shape (White and Garrot 1990, Powell 2000). Although we report fixed kernel estimates (with reference bandwidth) for comparison with other studies, we focus our discussion on MCP estimates, because of published reports of failures, or high variability of the kernel based estimations of home range, related to sample size (Hemson et al. 2005, , Downs et al. 2012, Signer and Balkenhol 2015, Bauder et al. 2015 ). Furthermore, based on our field experience, we also think that kernel method over-estimated home range for our studied animals in particular. The polygons obtained with $\mathrm{MCP}$ were also used to calculate overlap (percentage of area and size in ha) of home ranges between pairs of individuals (Powell 2000) using ArcGis 10.0.

\section{Habitat use and selection}

Based on local knowledge, we defined three types of habitat: crops (agroforestry systems), fallows (previously cultivated land abandoned for at least five years, always with a dense understory), and secondary forests (with tall trees, and lacking a dense understory). We walked across the community lands, especially where radio locations were obtained, and then mapped (using a GPS) all patches of the three habitat types (larger than -1 ha) where either radio tagged animals were present (radio locations), or track-plots were established (see below). Using this detailed map, we assigned each location to one of the three habitat types. We then constructed polygons using Google Earth ${ }^{\circledR}$ and later measured their areas (in ha) using ArcGis 10.0 to calculate habitat availability of each habitat.

We used habitat availability as a criterion to assess habitat use. The proportion of each type of habitat available was used to calculate the expected number of locations, under the null hypothesis of no selection (Garshelis 2000; Parroquin et al. 2010). A Chi Square $\left(\chi^{2}\right)$ test was used to evaluate whether individuals used the habitat according to availability (randomly) or not (selection) (Manly et al. 2002) under the considerations of design type I (i.e. individual animals are not identified, resources are censussed for the entire study area; Manly et al. 2002) for the data obtained by radio telemetry plots. We also performed tests for each individual followed with radio telemetry under the design type III (i.e. individuals are identified, resources are sampled or censussed for each animal; Manly et al. 2002). We also used the Standarized Selection Rate index (B) to assess habitat selection, but only considering data pooled from all individuals (with design type I). Values $>0.33$ of the index indicate positive selection, while values $<0.33$ indicate rejection of the habitat type under consideration (Manly et al. 2002).

We also evaluated habitat use and selection by analyzing the presence of indirect signs (i.e. tracks), under the considerations of design type II from Manly et al. (2002) where the use of resources is measured for each animal, but availability is measured at the population level. We opened eight trails separated $250 \mathrm{~m}$ from each other. At each trail we established 10 track plots of $1 \mathrm{~m}^{2}$ (see Simonetti and Huareco 1999), one every $50 \mathrm{~m}$ (Pacheco et al. 2003). We considered that if the maximum home range reported for paca is 4 ha (Beck-King et al. 1999; Wallace et al. 2010), then a $250 \mathrm{~m}$ separation would reduce the possibilities that the same individual could leave tracks on contiguous trails. We recorded paca tracks on track plots and noted the type of habitat in which every plot was established (e.g. crop, fallow, secondary forest). Trail position was independent of the radio tracked animals' ranges. Data on tracks were analyzed in a similar fashion as radio locations.

\section{RESULTS}

We captured five adult individuals between May and July of 2012, four females (F1 through F4) and one male (M1). Female F3's transmitter failed after 54 days (15 locations), so we did not include her data for further analysis. Female F1 was killed by hunters, so she provided only 22 effective locations. The two other animals were effectively located between 45 and 49 times (see Table 1). Before data acquisition we also estimated accuracy, based on White and Garrot (1990). We estimated that for readings within $50 \mathrm{~m}$ of the animal, our error was $-50 \mathrm{~m}$ at the beginning of the study, and $-30 \mathrm{~m}$ later on. We discarded 420 locations (out of 583) for which we suspected signal rebounds (which were surely due to the steep topography of the area), or that the difference between azimuths was $<20^{\circ}$.

\section{Home range size, dens and overlap}

Mean individual home range was 2.26 ha $(\mathrm{SD}=1.76$, MPC 95\%), and ranged from 1.50 to $2.97 \mathrm{ha}$. The mean home range for the two females (2.04 ha) was slightly smaller than the male's $(2.95 \mathrm{ha})$. We recorded only one core area for each individual, which ranged between 0.31 and 0.54 ha (mean = 0.41 ha, $S D=0.007 ;$ MPC 50\%, Table 1). We located dens at least two times for each individual (mean 2.25 per individual), except for F3, due to her damaged transmitter. Seven out of the nine dens found were located in fallows, whereas only one was located within a cacao agroforestry system (near a fallow 
Table 1. Paca (Cuniculus paca) home ranges and core areas at Remolinos, Alto Beni, Bolivia. $\mathrm{F}=$ females, $\mathrm{M}=$ males. All individuals were adults. $\mathrm{MCP}$ $=$ Minimum Convex Polygon, KF = Fixed Kernel.

\begin{tabular}{lccccc}
\hline & F1 & F2 & F3 & F4 & M1 \\
\hline Body mass (kg) & 9 & 10 & 8 & 9 & 10 \\
\hline Days monitored & 153 & 214 & 54 & 153 & 184 \\
\hline Effective locations ${ }^{+}$ & 22 & 47 & $15^{++}$ & 45 & 49 \\
\hline MPC 95\% (ha) & 1.64 & 2.96 & - & 1.5 & 2.95 \\
\hline FK 95\% (ha) & 5.53 & 5.57 & - & 2.36 & 3.46 \\
\hline Core area (ha) MPC 50\% & 0.42 & 0.54 & - & 0.31 & 0.36 \\
Core area (ha) KF 50\% & 1.38 & 1.15 & - & 0.47 & 0.65 \\
\hline Number of burrows & 2 & 2 & - & 2 & 3 \\
\hline
\end{tabular}

+Excluding outermost locations, rebounds of collar signal and difference between azimuths $<20$

${ }^{++}$This individual was excluded from the analysis due to low sample size

and a small stream). Home range overlap ranged between 50 and 99\%; the home ranges of females F4 and F2 overlapped $99 \%$ (1.5 ha), F4 overlapped 90\% (1.35 ha) of its home range with the male. Female F2, as well as the male M1, overlapped 50 and $56 \%$ of their home ranges (1.49-1.35 ha respectively) with F4. Finally F2 and M1 overlapped 1.67 ha (56 and 57\%) between each other. Core areas were less likely to overlap and they ranged between 14-24\% representing 0.07 ha of the occupied areas.

\section{Habitat use and selection}

We mapped a total of 38.1 ha within the study area, covering the entire home ranges of the five individuals captured ( $-9.4 \mathrm{ha})$ and an additional 28.6 ha which included the outer locations and some of the track plots. The largest portion of the landscape was fallow $(84.3 \%$, or $32.1 \mathrm{ha})$, followed by crops (4.67 ha, 12.3\%), and secondary forest (3.5\%, $1.32 \mathrm{ha})$.

Radio tagged pacas used only crops and fallows; we did not obtain any locations in secondary forest. Pacas did not use habitats according to availability $\left(\chi^{2}=32.33 ; \mathrm{df}=2 ; \mathrm{P}<0.001\right)$ : crops were positively selected $\left(B_{c}=0.69\right)$, while fallows and secondary forests were negatively selected $\left(\mathrm{B}_{\mathrm{F}}=0.30\right.$, and $\mathrm{B}_{\mathrm{fo}_{\mathrm{o}}}=$ 0 , respectively). Individual analyses were made for only three individuals (Figure 2), because the entire home range of F1 was included in fallows. At the individual level, females F2 and $\mathrm{F} 4$ used fallows and crops according to their availability (Table 2$)$, whereas the male positively selected crops $\left(\chi^{2}: 5.53\right.$, df $=1, \mathrm{P}<0.025)$.

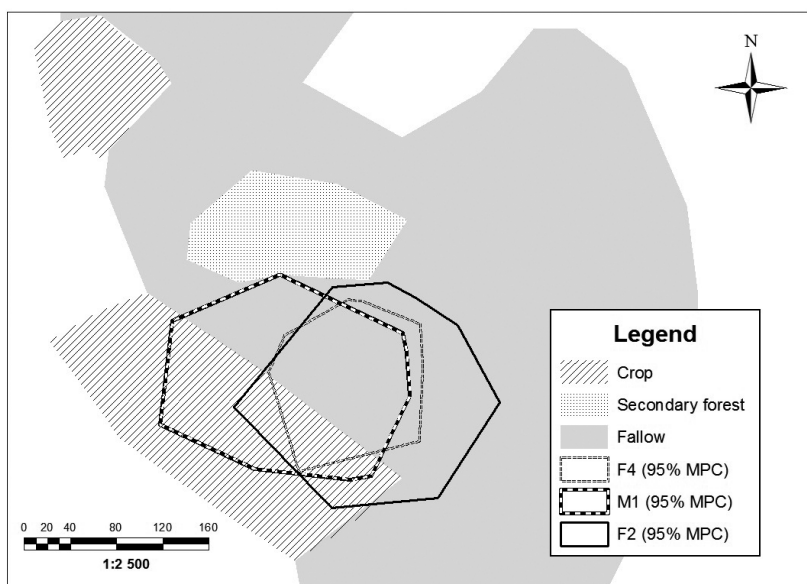

Figure 2. Home ranges of the three pacas (Cuniculus paca) considered for the study of habitat use, contour obtained with the Minimum Convex Polygon (MPC), $95 \%$ of the available locations.

Table 2. Observed Frequency (OF, locations per habitat), Expected Frequency (EF) and Chi-square $\left(\chi^{2}\right)$ test values for studied pacas. According to design III of Manly et al. (2002).

\begin{tabular}{lccccc}
\hline & Habitat & OF & EF & $\chi^{2}$ & P value \\
\hline F2 & Fallow & 39 & 36 & 1.04 & $\mathrm{p}>0.25$ \\
& Crop & 8 & 11 & & \\
F4 & Fallow & 39 & 37 & 0.56 & $\mathrm{p}>0.25$ \\
& Crop & 6 & 8 & & \\
M1 & Fallow & 20 & 28 & 5.53 & $\mathrm{p}<0.025$ \\
& Crop & 30 & 22 & & \\
\hline
\end{tabular}

We obtained data from track plots in seven sampling events between April and November 2012, activating 80 track plots each time (560 in total). We identified only two types of habitat within the area covered by track plots: fallow (41\%), and crops (59\%). We recorded 45 tracks of paca (and 119 tracks of other species of mammals, including Didelphis marsupialis, Mazama americana, Pecari tajacu, Dasyprocta punctata, Tapirus terrestris and Dasypus novemcinctus). We found 27 tracks $(60 \%)$ in crops and 18 in fallow (40\%). At this scale of analysis, pacas used habitats according to their availability $\left(\chi^{2}=0.03 ; \mathrm{df}=1 ; \mathrm{P}<0.75\right)$, and this was supported by the standardized selection rates $\left(\mathrm{B}_{\mathrm{C}}=0.51\right)$ for crops and $\left(B_{F}=0.49\right)$ for fallows.

\section{DISCUSSION}

The mean home range for pacas at our study site ( $2.3 \mathrm{ha}$, MPC) is within the values previously reported for this species (e.g. 0.7-3.4 ha, Marcus 1984; Beck-King et al. 1999). Our finding that the three females studied had smaller home ranges 
(mean $2.04 \mathrm{ha}$ ) than the single male radio tracked (2.95 ha) has not been reported previously, which may be partially explained by individual age, since the males studied by Marcus (1984) and Beck-King et al. (1999) were all juveniles. We assess other potentially explaining factors following.

In other mammals, males usually have larger home ranges and, given that larger individuals need larger home ranges, sexual dimorphism (i.e. larger males) may help explain that male pacas need larger home ranges (McNab 1963). However, larger home ranges for males are mostly seen in polygamous species (Nowak 1999), whereas pacas are thought to be monogamous (at least during the time of reproduction and growth of the cub, Pérez 1992; Wallace et al. 2010). Therefore, if male pacas really have larger home ranges than females, as suggested by our limited sample size, this species may not be strictly monogamous.

Another explanation may be related to the availability of resources for the only male studied, which might have been more limited or less concentrated than those for the females, resulting in a larger home range (e.g Jorge and Peres 2005). This pattern could also shift according to the reproductive season; where females would probably look more intensely for resources (when scarce), likely resulting in larger home ranges for females (Dubost et al. 2005).

Beck-King et al. (1999) reported two core areas for the adult female and only one for the juvenile male they studied. According to these authors, one of the core areas of the female included both dens and foraging areas, while the other one included only foraging areas. Two of our individuals (F2 and M1) had their dens away from any patches used during activity hours, so were not included in their home range estimates. The dens of female F1 were within her home range, which was entirely in fallow areas. It is possible that this female did not have to leave her daytime refuges to travel to foraging areas, as did the other pacas we radio tracked.

Although radiotagged pacas used fewer dens per individual than those studied by Beck-King et al. (1999: 2.25 vs. 3.5), we also found that males use more dens than females: 7 vs. 4 , and 4 vs. 2, respectively for Beck King et al. (1999) and our study. The most parsimonious explanation may also be related to the sexual size dimorphism in this species: larger individuals (males) would have larger home ranges, which in turn may harbor more dens.

Our home range overlaps (between 50 and 99\% of home ranges, and 14 and $24 \%$ of core areas) are in the range of those reported by Beck-King et al. (1999): 74\% of the home range, and below the $46 \%$ reported for core areas. These authors suggest that the relatively high overlap could mean intraspecific tolerance, as reported by Marcus (1984) who observed a group of female pacas foraging very close together in Panama. We also observed a group of three individuals foraging very close to one another $(\sim 10$ $\mathrm{m})$, but we could not distinguish the sex of the individuals (A. Arce and C. Benavides, unpublished data). Although we do not have similar observations for males, it is known that males of other rodents with monogamous reproductive system (e.g. Peromiscus californicus) show territorial defense behavior (Clutton-Brock 1989; Ribble and Salvioni 1990). Furthermore, Smythe and Brown de Guanti (1995) report that male pacas exclude each other aggressively. Studies seeking to confirm this behavior require larger sample sizes.

Other authors (Brown 1964; Maher and Lott 2000; McLoughlin et al. 2000) suggest that home range overlap is influenced mainly by the availability of food resources and greater abundance of key resources would allow greater overlap. Additionally, the availability of other resources such as refuges, or sites with high vegetation cover to avoid predators may also affect tolerance (Aliaga-Rossel et al. 2008; Goulart et al. 2009; Michalsky and Norris 2011, Norris et al. 2012) and should be an interesting aspect to explore in future studies: measuring the availability of food resources, presence of predators related to home range sizes, and how they might swift in time related to them.

Our radiotelemetry results suggest that pacas select agroforestry plantations over either fallows or secondary forests. This contrasts with the results of our track plot analysis and also with other studies based on tracks (Guzmán-Aguirre 2008; Huanca-Huarachi et al. 2011; Norris et al. 2012), which found that pacas prefer more mature forests and usually reject croplands. Possible causes are the type of crops (monocultures) where Guzmán-Agruirre (2008) studied pacas, while the ones in our study were highly diverse agroforestry plantations. There is evidence indicating that monocultures offer less favorable habitats for animals since they contain less heterogeneity, offering a short array of food resources (Daily et al. 2003; Perfecto et al. 2005; Barlow et al. 2007; Cassano et al. 2012). In our case the agroforestry plantations more closely resembled an open forest, and thus may have offered richer environments, with a higher abundance of fruits and more vegetation cover (Daily et al. 2003; Perfecto et al. 2005; Barlow et al. 2007; Cassano et al. 2012). Furthermore, pacas do not avoid hunters by using plantations, since hunters usually wait for them close to a fruiting tree, or search for them along trails.

The very low use of secondary forests by radiotagged pacas may be explained by the fact that this type of habitat represented $<4 \%$ of our study area. Therefore, we are not suggesting that secondary forests are not important for pacas, only that this type of habitat is not positively selected at our study site. On the other hand, the importance of fallows for pacas suggested by Guzmán-Aguirre (2008), and Parroquin et al. (2010) coincide with our finding that most dens were placed either in, or near 
fallow areas. Pacas tend to look for dense understory to establish their dens (Parroquin et al. 2010).

Habitat use may change seasonally depending on resource availability (Sinclair et al. 2005). The number of plant species with fruits suitable for mammal consumption in a Yungas Montane forest $(-1500 \mathrm{~m})$ peaks during the wet season (i.e. from December to April; Roldán and Larrea 2003), which is also common in other types of Neotropical forests (Leigh and Windsor 1985; Justiniano and Fredericksen 2000; Wallace and Painter 2002). Subsequent studies should evaluate whether habitat selection changes seasonally according to the availability of fruits.

\section{CONCLUSIONS}

Paca home ranges average 2.26 ha $(S D=1.76)$ at our study site. Although our sample size is very small, our results suggest that females have slightly smaller home range sizes than males. Pacas used agroforestry plantations and fallows similarly. Fallow areas may be especially important as refuges, while secondary forests are too rare to be of any significance for pacas at our study site, but we do not discard its potential importance. Our study highlights the importance of agroforestry systems for the sustainable management of pacas, at least where primary or secondary forests are lacking, because the species exploits agroforestry systems in a similar way as other habitats, and maintains home ranges similar in size to those reported in the available literature.

\section{ACKNOWLEDGEMENTS}

This study was funded by Ecotop S.R.L. We wish to deeply thank Rigoberto Supa and Ignacia Muchía for all the help and care they gave us during the field work we developed, they made us feel home and taught us so much. We also wish to thank Fortunato Velasquez, Casto Muchía, Fermín Zavala, Santiago Mamani, Rómulo Quispe, Roberto Cárdenas, and all the children at Remolinos for their help and company during our stay at their community. We wish to thank as well Enzo Aliaga-Rossel and Adriana Rico for their comments on an earlier version of this manuscript, Mauricio Ocampo and Daniel Sanginez for their help with GIS analyses. And finally we thank Joe Fragoso, Gustavo Kattan, Andrew Noss, and three anonymous reviewers for their comments that improved this manuscript.

\section{REFERENCES}

Aliaga-Rossel, E. 2004. Landscape use, ecology and home range of the agouti (Dasyprocta punctata). Master's dissertation, University of New York, New York. 78p.

Aliaga-Rossel, E.; Kays, R.; Fragoso, J. 2008. Home-range use by the Central American agouti (Dasyprocta punctata) on Barro Colorado Island, Panamá. Journal of Tropical Ecology, 24: 367-374.
Aquino, R.; Gil, D.; Pezo, E. 2009. Aspectos ecológicos y sostenibilidad de la caza del majás (Cuniculus paca) en la cuenca del río Itaya, Amazonía peruana. Revista Peruana de Biología, 16: 67-72.

Aquino, R.; Meléndez, G.; Pezo, E.; Gil, D. 2012. Tipos y formas de dormir de majás (Cuniculus paca) en la cuenca alta del río Itaya. Revista Peruana de Biología, 19: 27-43.

Aspirilla-Perea, J.; López-Perea, J.J.; Viveros-Riveros, J.A.; JiménezOrtega, A.M. 2011. Relación entre abundancia relativa y el aprovechamiento de Cuniculus paca (Guagua, Tepezcuintle) en comunidades negras de la cuenca del Atrato, Colombia. Maztozoología Neotropical, 18: 301-306.

Beck-King, H.; Von Helversen, O.; Beck King, R. 1999. Home range, population density and food resources of Agouti paca (Rodentia: Agoutitdae) in Costa Rica: A study using alternative methods. Biotropica, 31: 675-685.

Barlow. J; Gardner, T.A.; Araujo, I.S.; Avila-Pires, T.C. ; Bonaldo, A.B. ; Costa, J.E.; et al. 2007. Quantifying the biodiversity value of tropical primary, secondary, and plantation forests. Proceedings of the National Academy of Sciences of the United States of America, 104: 18555-18560.

Bauder, J.M.; Breininger, D.R.; Bolt, M.R.; Legare, M.L.; Jenkins, C.L.; McGarigal, K. 2015. The role of the bandwidth matrix in influencing kernel home range estimates for snales using VHF telemetry data. Wildlife Research, 42: 437-453.

Brown, J.L.1964. The evolution of diversity in avian territorial systems. Wilson Bulletin, 76: 160-169.

Cassano, C.; Barlow, J.L.; Pardini, R. 2012. Large mammals in an agroforestry mosaic in the Brazilian Atlantic forest. Biotropica, 44: 818-825.

Castellanos, G. 2006. Sobre el ámbito hogareño y los hábitos alimentarios de un carnivoro en un ambiente suburbano: el Cacomixtle (Bassariscus astutus) en la Reserva Ecológica "El pedregal de San Ángel”. Bachelor's dissertation, Universidad Nacional Autónoma de México, Mexico. 85p.

Clutton-Brock, T.H. 1989. Review Lecture: Mammalian Mating Systems. Proceedings of the Royal Society of London, 236: 339-372.

Daily, G.C.; Ceballos, G.; Pacheco, J.; Suzan, G.; Sanchez-Azofeifa, A. 2003. Countryside biogeography of neotropical mammals: conservation opportunities in agricultural landscapes of Costa Rica. Conservation Biology, 17: 1814-1826.

Downs, J.A.; Heller, J.H.; Loraamm, R.; Oppenheim Stein, D.; McDaniel, C.; Onorato, D. 2012. Accuracy of home range estimators for homogeneus and inhomogeneus point patterns. Ecological Modeling, 225: 66-73.

Dubost G.; Henry, O.; Comizzoli, P. 2005. Seasonality of reproduction in the three largest terrestrial rodents of French Guiana forest. Mammalian Biology, 70: 93-109.

Fahrig, L.; Baudry, J.; Brotons, Ll.; Burel, F.G.; Crist, T.O.; Fuller, R.J.; Sirami, C.; Siriwardena, G.M.; Martin, J.L. 2011. Functional landscape heterogeneity and animal biodiversity in agricultural landscapes. Ecology Letters, 14: 101-112.

Gallina, S.; Pérez-Torres, J.; Guzmán-Aguirre, C. 2012. Use of the paca, Cuniculus paca (Rodentia: Agoutidae) in the Sierra 
de Tabasco State Park, Mexico. Revista de Biología Tropical, 60:1345-1355.

Garshelis, D. 2000. Delusions in habitat evaluation: Measuring use, selection and importance. In: Boitani, L.; Todd, F. (Ed.). Research techniques in animal ecology: Controversies and Consequences. Columbia University Press, New York, p.111-164.

Goulart, F.V.B.; Cáceres, N.C.; Graipel, M.E.: Tortato, M.A.; Ghizoni, I.R.; Rodrigues Oliveira-Santos, R.G. 2009. Habitat selection by large mammals in a southern Brazilian Atlantic Forest. Mammalian Biology, 74: 182-190.

Guzmán-Aguirre, C. 2008. Uso, preferencia de hábitaty aprovechamiento del Tepezcuintle, Cuniculus paca (Linneo, 1766) en el Parque Estatal de la Sierra de Tabasco, México. Master's dissertation, Instituto de Ecología A.C, Veracruz. 51p.

Hemson, G.; Johnson, P.; South, A.; Kenwards, R.; Ripley, R.; Macdonald, D. 2005. Are kernels the mustard? Data from global positioning system (GPS) collars suggest problems for kernel home range analyses with least-squares cross-validation. Journal of Animal Ecology, 74: 455-463.

Huanca-Huarachi, G.; Herrera, J.C.; Noss, A.J. 2011. Population density and habitat use of the paca (Cuniculus paca) in the north of the Amboró-Carrasco conservation complex. Ecología en Bolivia, 46: 4-13.

Jorge, M.S.P.; Peres, C.A. 2005. Population density and home range size of Red-Rumped Agoutis (Dasyprocta leporine) within and outside a natural Brazil nut stand in Southern Amazonia. Biotropica, 37: 317-321

Justiniano, M. J.; Fredericksen, T. S. 2000. Phenology of tree species in Bolivian dry forests. Biotropica, 32: 276-281.

Leigh, E.G.; Windsor, D.M. 1985. Forest production and regulation of primary consumers on Barro Colorado Island. In: Leigh, E.G.; Stanley Rand, A.; Windsor, D.M. (Ed.). The Ecology of a Tropical Forest, Seasonal Rhythms and Long-Term Changes. Smithsonian Institution Press, Washington D.C, p.11-122.

Maher, C.R.; Lott, D.F. 2000. A review of ecological determinants of territoriality within vertebrate species. The American Midland Naturalist, 143: 1-29.

Manly, B.F.J.; Mc.Donald, L.L.; Thomas, L.D.; Mc.Donald, T.T.; Erickson, W.P. 2002. Resource Selection by animals: Statistical design and analysis for field studies. Kluwer Academic Publishers, New York, Boston, Dordrecht, London, Moscow, 220p.

Marcus, Y. 1984. Behavioral ecology of paca (Agouti paca) on Barro Colorado Island, Panamá. Master's dissertation, University of Maine, Maine, 180p.

McLoughlin, P.; Fergunson, S.; Messier, F. 2000. Intraspecific variation in home range overlap with habitat quality: a comparison among brown bear populations. Evolutionary Ecology, 14: 39-60.

McNab, B.K. 1963. Bioenergetics and the determination of home range size. The American Naturalist, 97: 133-140.

Michalsky, F.; Norris, D. 2011. Activity pattern of Cuniculus paca (Rodentia: Cuniculidae) in relation to lunar illumination and other abiotic variables in the southern Brazilian Amazon. Zoologia (Curitiba), 28: 701-708.
Millspaugh, J.J.; Kesler, D.C.; Kays, R.W.; Gitzen, R.A.; Schulz, J.H.; Rota, C.T.; Bodinof, C.M.; Belant, J.J.; Keller, B.J. 2012. Wildlife radiotelemetry and remote monitoring. In: Silvy, N. (ed.). The wildlife techniques manual. v. 1. Johns Hopkins University Press, Baltimore, p.258-283.

Norris, D.; Ramírez, J. M.; Zacchi, C.; Galetti, M. 2012. Mastofauna de médio e grande porte no Núcleo Caraguatatuba, Parque Estadual Serra do Mar, SP, Brasil. (http://www.biotaneotropica. org.br/v12n2/pt/abstract?inventory+bn00312022012 6). Accessed on $12 / 9 / 2014$.

Nowak, R. 1999. Walker's mammals of the world, v. 6. Johns Hopkins University Press, Baltimore, 2160p.

Pacheco, L.F.; Guerra, F.; Ríos-Uzeda, B. 2003. Eficiencia de atrayentes para carnívoros en bosques yungueńos y praderas alto andinas de Bolivia. Mastozoología Neotropical, 10: 167-176.

Parroquin, J.; Gallina, S.; Aguirre, G.; Pérez, J. 2010. El tepezcuintle: estrategias para su aprovechamiento con base en la evaluación de su población y hábitat en el ejido Loma de Oro, Uxpanapa, Veracruz, México. In: Secretaría de Educación del Gobierno del Estado de Veracruz de Ignacio de la Llave (Ed.). Uso y manejo de fauna silvestre en el norte de Mesoamérica, Secretaría de Educación de Veracruz, México, p.137-160.

Pérez, E.M. 1992. Agouti paca. Mammalian Species, 404: 1-7.

Pérez, E.; Pacheco, L.F. 2006. Damage by large mammals to subsistence crops in a montane forest of Bolivia. Crop Protection, 25: 933-939.

Perfecto, I.; Vandermeer, J.; Mas, A.; Pinto, L.S. 2005. Biodiversity yield, and shade coffee certification. Ecological Economics, 54: 435-446.

PIAF-El CEIBO. 2002. Vegetación de Alto Beni. In: Sub-Programa Aprovechamiento Forestal (Ed.). Guía de especies forestales de Alto Beni, El Ceibo LTDA, Sapecho, p.3-4.

Powell, R. 2000. Animal home ranges and territory and home range estimators. In: Boitani, L.; Tod, F. (Ed.). Research techniques in animal ecology: Controversies and Consequences, Columbia University Press, New York, p.65-103.

Queirolo, D.; Vieira, E.; Emmons, L.; Samudio, R. 2008. Cuniculus paca. IUCN 2012. IUCN Red List of Threatened Species (www. iucnredlist.org). Accessed on 30/4/ 2013.

Quintana, G.; Vargas, L. 1995. Uso de la tierra y población. In: Quintana, G.; Vargas, L. (Ed.). Guí popular de plantas utilizadas por los mosetenes de Covendo, Santa Ana y Muchanes (Alto Beni, Bolivia), Fondo Nacional Para el Medio Ambiente (FONAMA), La Paz, p.5.

Redford, K.H.; Robinson, J.G. 1991. Subsistence and commercial uses of wildlife in Latin America. In: Redford, K. H.; Robinson, J. G. (Ed.). Neotropical wildlife use and conservation. The University of Chicago Press, Chicago, p.6-23.

Ribble, D.O.; Salvioni, M. 1990. Social organization and nest coocupancy in Peromyscus californicus, a monogamous rodent. Behavioral Ecology and Sociobiology, 26: 9-15.

Rodriguez, E.; Ortega, A.M. 2012. Valoración de unidades de servicios de los ecosistemas: El caso de la Guanta (Cuniculus paca). Proyecto Guanta. (http://departamentos.uleam.edu.ec/ investigacion/files/2012/01/PROYECTO-GUANTA-.pdf). Accessed on 19/3/2013. 
Roldán, A.I.; Simonetti, J.A. 2001. Plant-Mammal interactions in tropical Bolivian forests with different hunting pressures. Conservation Biology, 15: 617-623.

Roldán, A.I.; Larrea, D.M. 2003. Fenología de 14 especies arbóreas y zoócoras de un bosque yungeño en Bolivia. Ecología en Bolivia, 38: $125-140$.

Santos-Fita, D.; Naranjo, E; Rangel-Salazar; J. 2012. Wildlife uses and hunting patterns in rural communities of the Yucatan Peninsula, Mexico. Journal of Ethnobiology and Ethnomedicine, 8: 38, doi: 10.1186/1746-4269-8-38.

Signer, J.; Balkenhol, H. 2015. Reproducible home ranges (rhr): A new user-friendly $\mathrm{R}$ package for analyses of wildlife telemetry data. Tools and Technology, 39: 358-363.

Simonetti, J.A.; Huareco, I. 1999. Uso de huellas para estimar diversidad y abundancia relativa de los mamíferos de la reserva de la Biosfera - Estación Biológica del Beni, Bolivia. Mastozoologia Neotropical, 6: 139-144.

Sikes, R.S.; Gannon, W.L.; The Animal Care And Use Committee of The American Society of Mammalogists. 2011. Guidelines of the American Society of Mammalogists for the use of wild mammals in research. Journal of Mammalogy, 92: 235-253.

Sinclair, A.R.E.; Fryxell, J.; Caughley, G. 2005. Wildlife ecology, conservation and management. Blackwell Science, Oxford, 450p.

Smythe, N.; Brown de Guanti, O. 1995. La paca silvestre. In: Smythe, N.; Brown de Guanti, O. 1995 (Ed.). Guia de Conservación $N^{\circ}$ 26: La domesticación y cría de la paca (Agouti paca), FAO (Food and Agriculture Organization of the United Nations), Roma, p.9-11.
Sutherland, W. 2000. Exploitation. In: Sutherland, W (Ed.). The conservation handbook: Research, management and policy. Black Science LTD, London, p.203-224.

Wallace, R.B.; Painter, R.L.E. 2002. Phenological patterns in a southern Amazonian tropical forest: implication for sustainable management. Forest Ecology and Management, 160: 19-33.

Wallace, R.B.; Aliaga-Rossel, E.; Viscarra, W.; Siles, T. 2010. Cuniculidae, Dasyproctidae, Dynomidae y Myocastoridae. In: Wallace, R.B.; Gómez, H.; Porcel, Z.; Rumiz, D. (Ed.). Distribución, ecología y conservación de los mamíferos medianos y grandes de Bolivia, Fundación Simón I. Patiño, Santa Cruz, p.729-762.

White, G.C.; Garrot, C. 1990. Analysis of wildlife radio-tracking data. Academic Press, San Diego, 383p.

Zapata, G. 2001. Sustentabilidad de la cacería de subsistencia: el caso de cuatro comunidades quichuas en la Amazonía Nororiental Ecuatoriana. Mastozoología Neotropical, 8: 59-66.

Zolotoff-Pallais, J.; Lezama, M. 2009. IV Sujeción y confinamiento por grupo taxonómico. In: Zolotoff-Pallais, J.; Lezama, M. (Ed.). Manipulación de fauna silvestre decomisada en Nicaragua, USAID, Nicaragua, p.14.

Zucaratto, R.; Carrara, R.; Siqueira-Franco, B.K. 2010. Dieta da paca (Cuniculus paca) usando métodos indiretos numa área de cultura agrícola na Floresta Atlântica brasileira. Biotemas, 23: 235-239.

Received: $15 / 11 / 2016$

Accepted: 07/06/2017 
